\title{
ETÄOPETUKSESTA MONIMUOTO-OPETUKSEEN
}

S uomalaiset aikuiskasvattajat ovat olleet ensimmäisten joukossa soveltamassa lähiopetukselle vaihtoehtoista ja täydentävää opetuksen muotoa - etäopetusta. Yhdysvaltoihin perustettiin ensimmäinen kirjeopisto vuonna 1891 ja jo parinkymmenen vuoden kulutta Suomessa sovellettiin vastaavaa järjestelmää. Kansalais- ja kotiopintoliike aloitti opintojen kirjeellisen ohjauksen vuonna 1912 ja jo vuonna 1920 perustettiin Kansanvalistusseuran kirjeopisto.

Vuonna 1986 muistionsa jättänyt monimuotoopetuksen työryhmä (opetusministeriön työryhmän muistioita 39) määritteli etäopetuksen opetusmuodoksi, jossa opiskeluaineisto välitetään opiskelijalle postitse, radion, television tai muun datasiirron avulla ja jossa opiskelijalla on tarvittaessa yhteysmahdollisuus opettajaan kirjeitse, puhelimitse tai muun vastaavan välittäjän kautta.
Onnistuessaan etäopetus tarjoaa ja on tarjonnut aikuiselle, itsenäiselle henkilölle mahdollisuuden joustavaan, riippumattomaan ja taloudelliseen opiskeluun ja itsensä kehittämiseen. Monista kansainvälisistä ja suomalaisista tutkimuksista on käynyt ilmi etäopetuksen monet myönteiset vaikutukset. On onnistuttu lisäämään opiskelumahdollisuuksien tasa-arvoisuutta, opiskelu on tullut joustavammaksi ja monet opintojen esteet ovat pienentyneet. Etäopiskeluun liittyy tietenkin myös ongelmia, siitä viestii $\mathrm{mm}$. suuri opintonsa keskeyttäneiden määrä.

\section{Miksi uusi käsite monimuoto-opetus?}

Monimuoto-opetus käsitteenä vilahteli keskusteluissa jo 1970-luvulla. Muutamat oppilaitokset käyttivät tätä käsitettä aivan tietoisesti ko- 
rostaessaan eroa tavanomaiseen tapaan organisoida opetusta. Suomalaisista koulutusorganisaatioista mm. Merkonomien Jatkokoulutuskeskus MJK, E-Instituutti ja Markkinointi-instituutti käyttivät tätä käsitettä ennen sen " virallistamista". Kaikille oppilaitoksille oli ja on tyypillistä se, että etäopetuksella tuetun itseopiskelun ja perinteisemmän lähiopetuksen lisäksi olennaisena osana on suunnitelmallinen työssä oppiminen.

Käsitteen eräänlainen virallistuminen tapahtui 1980-luvun puolivälin jälkeen, jolloin edellä mainittu työryhmämuistio asiasta valmistui. Vuonna 1989 aikuiskoulutusneuvosto tarkensi käsitteen "virallista" määritelmää. Sen mukaan monimuoto-opetus on tietylle kohderyhmälle suunnitelmalliseksi kokonaisuudeksi yhdistettyä lähi- ja etäopetusta sekä itseopiskelua, joita tukee opiskelijan ohjaus ja neuvonta. Lisäksi korostetaan, että opetuksessa voidaan käyttää hyväksi sähköistä viestintätekniikkaa, telemaattisia palveluja ja tietotekniikkaa. Eri aikuiskoulutusorganisaatiot voivat järjestää monimuoto-opetusta yhteistyönä.

\section{Monimuoto-opetuksen etuja}

Monimuoto-opetuksen käsitteenä ja ilmiönä osakseen saama myönteinen huomio selittynee sillä, että monimuotoisen opetuksen ja opintojen organisoinnin uskotaan hyvin edistävän aikuiskoulutuksen keskeisten tavoitteiden saavut- tamista. Näitä keskeisiä tavoitteita ovat mm. opiskelun joutavuuden ja saavuttavuuden lisääntyminen, opiskelun tuloksellisuuden paraneminen sekä opetuksessa käytettävien resurssien taloudellinen ja tarkoituksenmukainen käyttö (vrt. esimerkiksi Telemaattiset kulttuuripalvelut -työryhmän muistiota vuodelta 1990).

\section{Käsitteen sisältö: opetus, ohjaus, opiskelu}

Onko uusi käsite - monimuoto-opetus tarpeen? Olisiko ollut mahdollista käyttää jatkossakin käsitettä etäopetus? Onko riittävä peruste uuden käsitteen käytölle se, että eri tavoin vahvistetaan etäopetuksessakin tavalla tai toisella käytössä olleita komponentteja; lähi-, etä- ja itseopiskelua? Vai onko monimuodossa nyt jotain todella uutta? Näyttää siltä, että huolimatta viime vuosien vilkkaasta monimuotokokeilusta ja -keskustelusta missään ei olla tehty todella pysähdyttävää opetuksen, ohjauksen ja opiskelun integroivaa kuvausta monimuoto-opetuksen olemuksen selkeyttämiseksi.

Tämän kirjoittajaryhmä on palaverissaan jäsentänyt monimuoto-opetuksen keskeisten osien olemusta ja keskinäistä suhdetta. Jokainen meistä on usean vuoden työskennellyt asian parissa kouluttajana, tutkijana ja hallintotehtävissä. Saadaksemme monimuoto-opetuskentässä käytettävät käsitteet ja niiden väliset suhteet vakiintuneemmalle tasolle tarjoamme jatkokeskustelujen pohjaksi seuraavan kuvaustavan.

\section{Kuvio 1. Monimuoto-opetuksen rakentuminen}

\begin{tabular}{|c|c|c|c|}
\hline \multicolumn{4}{|c|}{ Opetus, ohjaus ja opiskelu } \\
\hline \multirow{2}{*}{ Organisointi } & \multirow{2}{*}{$\begin{array}{l}\text { Keskinäinen } \\
\text { yhteys }\end{array}$} & \multicolumn{2}{|l|}{ Toteutus } \\
\hline & & Aika ja paikka & Tapa \\
\hline 1. LÄHI & Välitön & Samat & $\begin{array}{l}\text { Välitön } \\
\text { persoonallinen } \\
\text { vuorovaikutus }\end{array}$ \\
\hline 2. ETÄ & Välineellinen & $\begin{array}{l}\text { Sama tai } \\
\text { eri aika ja } \\
\text { eri paikka }\end{array}$ & $\begin{array}{l}\text { Vuorovaikutt. } \\
\text { välineet ja } \\
\text { materiaalit }\end{array}$ \\
\hline 3. ITSE & Puuttuu & $\begin{array}{l}\text { Eri aika ja } \\
\text { eri paikka }\end{array}$ & $\begin{array}{l}\text { Materiaalit ja } \\
\text { välineet }\end{array}$ \\
\hline
\end{tabular}


Jo aikaisemmin mainitussa aikuiskoulutusneuvoston määritelmässä olivat mukana kuviossa esitetyt organisointimuodot: lähi, etä ja itse. Käsityksemme mukaan näitä erottavaksi piirteeksi nousee ohjaajan ja ohjattavan keskinäinen yhteys. Se voi olla joko välitön, välineellinen tai puuttua kokonaan. Eroja syntyy myös toteutuk- sessa. Olemme eritelleet toteutuksessa aika- ja paikkatekijän sekä toteutustavan. Näiden tekijöiden osalta erittelemme kunkin organisointitavan (lähi, etä, itse) ominaispiirteitä. Kuviossa 2. havainnollistamme organisointitapoja konkreettisemmin.

Kuvio 2. Esimerkkejä monimuoto-opetuksen toteutustavoista

\begin{tabular}{|c|c|c|c|c|}
\hline \multicolumn{4}{|c|}{ Opetus, ohjaus ja opiskelu } & \\
\hline \multirow{2}{*}{$\begin{array}{l}\text { Organi- } \\
\text { sointi }\end{array}$} & \multirow{2}{*}{$\begin{array}{l}\text { Keskinäi- } \\
\text { nen yh- } \\
\text { teys }\end{array}$} & \multicolumn{2}{|l|}{ Toteutus } & \\
\hline & & $\begin{array}{l}\text { Aika ja } \\
\text { paikka }\end{array}$ & Tapa & \\
\hline 1. LÄHI & Välitön & Samat & $\begin{array}{l}\text { Välitön } \\
\text { persoo- } \\
\text { nallinen } \\
\text { vuoro- } \\
\text { vaikutus }\end{array}$ & $\begin{array}{l}* \text { Oppitunnit menetelmineen } \\
* \text { Opintopiirit }\end{array}$ \\
\hline 2. ETÄ & $\begin{array}{l}\text { Välineel- } \\
\text { linen }\end{array}$ & $\begin{array}{l}\text { Sama tai } \\
\text { eri aika } \\
\text { ja eri } \\
\text { paikka }\end{array}$ & $\begin{array}{l}\text { Vuoro- } \\
\text { vaikutt. } \\
\text { välineet } \\
\text { ja mate- } \\
\text { riaalit }\end{array}$ & $\begin{array}{ll}* & \text { Opintokirjeet } \\
* & \text { Puhelinopetus } \\
* & \text { Videoneuvottelu } \\
* & \text { Tietokoneavust. opetus }\end{array}$ \\
\hline 3. ITSE & Puuttuu & $\begin{array}{l}\text { Eri aika } \\
\text { ja eri } \\
\text { paikka }\end{array}$ & $\begin{array}{l}\text { Materi- } \\
\text { aalit ja } \\
\text { välineet }\end{array}$ & $\begin{array}{l}* \text { Kirjallisuus } \\
* \text { Tietokoneet } \\
* \text { Av-materiaalit }\end{array}$ \\
\hline
\end{tabular}

(C) 1991/Hätönen, Koro, Mäkinen, Vaherva

Usein on esitetty kysymys, riittääkö monimuoto-opetuksen käsitteen sisällöksi esimerkiksi lähija etäopetus tai etä- ja itseopiskelu. Esitämme kuvauksemme perusteella, että monimuoto-opetuksen tulee sisältää kaikki kolme tekijää, lähiopetuksen, etäopetuksen ja itseopiskelun. On toki mahdollista, että yksittäinen opiskelija suorittaa valintansa mukaan osioita suunnitellusta monimuotokokonaisuudesta omien tavoitteittensa mukaisesti.

HELJÄ HÄTÖNEN, JKKA KORO, ANNELI MÄKINEN \& TAPIO VAHERVA
Korostamme, että monimuoto-opetuksessa keskeisiä ovat tuloksellisen oppimisen tukeminen erilaisin ratkaisuin, opiskelijan ja opettajan vuorovaikutuksen monensuuntaisuus ja joustavuus, oppijan omaohjauksisuus sekä oppimisen arviointi oppijan itsensä suorittamana. Välineet ja menetelmät ovat tukemassa näitä prosesseja.

Toivomme, että keskustelu monimuoto-opetuksen käsitteestä ja sisällöstä jatkuisi — tämänkin esityksen pohjalta. 